\title{
Colorectal carcinomas in MUTYH-associated polyposis display histopathological similarities to microsatellite unstable carcinomas
} Maartje Nielsen ${ }^{1}$, Noel FCC de Miranda ${ }^{2}$, Marjo van Puijenbroek ${ }^{2}$, Ekaterina S Jordanova ${ }^{2}$, Anneke Middeldorp ${ }^{2}$, Tom van Wezel $^{2}$, Ronald van Eijk $^{2}$, Carli MJ Tops ${ }^{1}$, Hans FA Vasen ${ }^{3,4}$, Frederik J Hes ${ }^{1}$ and Hans Morreau*2

Address: ${ }^{1}$ Center for Human and Clinical Genetics, Leiden University Medical Center, Leiden, The Netherlands, ${ }^{2}$ Department of Pathology, Leiden University Medical Center, Leiden, The Netherlands, ${ }^{3}$ Department of Gastroenterology, Leiden University Medical Center, Leiden, The Netherlands and ${ }^{4}$ The Netherlands Foundation for the Detection of Hereditary Tumours, Leiden, The Netherlands

Email: Maartje Nielsen - M.Nielsen@lumc.nl; Noel FCC de Miranda - N.F.Miranda@lumc.nl; Marjo van

Puijenbroek - M.van_Puijenbroek@lumc.nl; Ekaterina S Jordanova - K.Jordanova@lumc.nl; Anneke Middeldorp - J.W.Middeldorp@lumc.nl; Tom van Wezel - T.van_Wezel@lumc.nl; Ronald van Eijk - R.van_Eijk@lumc.nl; Carli MJ Tops - C.M.J.Tops@lumc.nl;

Hans FA Vasen - H.F.Vasen@lumc.nl; Frederik J Hes - F.J.Hes@lumc.nl; Hans Morreau* - J.Morreau@lumc.nl

* Corresponding author

Published: 15 June 2009

BMC Cancer 2009, 9:184 doi:10.1 |86/147|-2407-9-184
Received: 20 February 2009

Accepted: 15 June 2009

This article is available from: http://www.biomedcentral.com/147I-2407/9//84

(c) 2009 Nielsen et al; licensee BioMed Central Ltd.

This is an Open Access article distributed under the terms of the Creative Commons Attribution License (http://creativecommons.org/licenses/by/2.0), which permits unrestricted use, distribution, and reproduction in any medium, provided the original work is properly cited.

\begin{abstract}
Background: MUTYH-associated polyposis (MAP) is a recessively inherited disorder which predisposes biallelic carriers for a high risk of polyposis and colorectal carcinoma (CRC). Since about one third of the biallelic MAP patients in population based CRC series has no adenomas, this study aimed to identify specific clinicopathological characteristics of MAP CRCs and compare these with reported data on sporadic and Lynch CRCs.

Methods: From 44 MAP patients who developed $\geq$ I CRCs, 42 of 58 tumours were analyzed histologically and 35 immunohistochemically for $\mathrm{p} 53$ and beta-catenin. Cell densities of CD3, CD8, CD57, and granzyme $B$ positive lymphocytes were determined. KRAS2, the mutation cluster region (MCR) of APC, p53, and SMAD4 were analyzed for somatic mutations.

Results: MAP CRCs frequently localized to the proximal colon $(69 \%, 40 / 58)$, were mucinous in $21 \%$ (9/42), and had a conspicuous Crohn's like infiltrate reaction in 33\% (13/40); all of these parameters occurred at a higher rate than reported for sporadic CRCs. Tumour infiltrating lymphocytes (TILs) were also highly prevalent in MAP CRCs. Somatic APC MCR mutations occurred in $14 \%(5 / 36)$ while $64 \%(23 / 36)$ had KRAS2 mutations (22/23 c.34G>T). G>T tranversions were found in $p 53$ and SMAD4, although the relative frequency compared to other mutations was low.

Conclusion: MAP CRCs show some similarities to micro-satellite unstable cancers, with a preferential proximal location, a high rate of mucinous histotype and increased presence of TILs. These features should direct the practicing pathologist towards a MAP aetiology of CRC as an alternative for a mismatch repair deficient cause. High frequent $G>T$ transversions in $A P C$ and KRAS2 (mutated in early tumour development) but not in P53 and SMAD4 (implicated in tumour progression) might indicate a predominant MUTYH effect in early carcinogenesis.
\end{abstract}




\section{Background}

MUTYH-associated polyposis (MAP) is an autosomal recessive disorder, which may be responsible for approximately $0.5-1 \%$ of colorectal carcinomas (CRCs). [1,2] Most biallelic MUTYH mutation carriers are reported to develop multiple polyps (typically between 10-500). [3,4] However, in seven population based CRC studies, 15 out of $39(38 \%)$ proven biallelic MUTYH mutation carriers had no polyps besides their CRC while seven $(18 \%)$ had a limited number of adenomas (i.e. $<10)$. $[1,2,5-9]$ Therefore, the practicing pathologist should also consider biallelic MUTYH mutations in CRC patients with none or less than 10 polyps.

The MUTYH protein is a base excision repair (BER) glycosylase involved in the repair of DNA damage resulting from the oxidation of guanine nucleotides. The oxidation product of guanine, 8-oxo-7,8-dihydro-2'-deoxyguanosine (8-oxoG), readily mispairs with adenosine nucleotides during DNA replication. MUTYH acts by scanning the newly synthesized DNA strand for any mispaired adenines, either with guanines or 8-oxoG's, and excising them. A dysfunctional MUTYH protein increases the occurrence of somatic G>T transversions. For instance, somatic mutations in the APC gene in MAP tumours involve almost exclusively $\mathrm{G}>\mathrm{T}$ transversions, an observation that led to the discovery of the MAP syndrome.[10] Similarly, the most prevalent KRAS2 mutation in MAP tumours is a $\mathrm{G}>\mathrm{T}$ transversion at codon 12 (c.34G>T), which was reported to be present in $64 \%$ of MAP carcinomas.[11] Such mutation is infrequent in sporadic CRCs, according to published consecutive series.[12]

Recently it was reported that MAP CRCs are often neardiploid (52\%) and commonly contain chromosomal regions of copy neutral loss of heterozygosity (LOH) (71\%). In copy-neutral LOH there is no loss of genetic material and this can arise via mitotic recombination, non-disjunction, or deletion and reduplication events. This is in contrast to sporadic colon cancer, where physical loss of genetic material is the main characteristic.[13]

Another set of CRCs with deficiencies in DNA repair are the mismatch repair deficient tumours. Mismatch repair deficient CRCs with high-microsatellite instability (MSIhigh) arise in the context of the Lynch syndrome or have a sporadic origin due to somatic inactivation of $h M L H 1$. MSI-high tumours have characteristic histological and molecular features: they are most often near-diploid and arise preferentially in the right side of the colon. They have a high prevalence of mucinous and medullary histotypes, poor differentiation, a Crohn's-like lymphocytic reaction, and a high amount of (intra-epithelial) tumour infiltrating lymphocytes (TILs). These characteristics are currently employed for diagnostic purposes and may have implications for patient treatment and prognosis. [14-17]

In the present study we describe histological and molecular aspects of MAP carcinomas in a Dutch cohort, and compare these with data available in literature of consecutive series of sporadic, MSI-high (sporadic), and Lynch syndrome-derived CRCs. The aim of this study was to identify specific characteristics that would aid in the diagnosis of MAP CRCs and in differentiation from carcinomas arising from distinct genetic backgrounds.

\section{Methods \\ Patients}

Fifty-seven MAP families, from which clinical data were available, were studied. Informed consent was obtained according to protocols approved by the Leiden University Medical Center ethics review board (02-2004). These families include 57 index-patients with biallelic homozygous or compound heterozygous MUTYH mutations and 22 siblings with biallelic MUTYH mutations. Forty indexpatients have been described previously in lesser detail.[3] One patient was reported to have CRC stage A according to the modified Astler-Coller guidelines at age 21, but after re-evaluation appeared to have high grade dysplasia (carcinoma in situ) and was not included in this series of MAP carcinomas. To date, 56\% (44/79) of the carriers have developed CRC. A total of 58 CRCs were diagnosed in these 44 MAP patients, composed of 26 males and 18 females. Hematoxylin and eosin (H\&E) stained slides and tissue material from 42 and 38 CRCs, respectively, belonging to $35 \mathrm{MAP}$ patients, could be retrieved from 23 pathology laboratories throughout The Netherlands.

\section{Histological examination}

Histological tumour type and grade were independently assessed by two observers ( $\mathrm{HM}$ and $\mathrm{MN}$ ) according to the World Health Organization classification.[18] Staging was performed according to the modified Astler-Coller (MAC) and the American Joint Committee on Cancer (AJCC) TNM staging system guidelines. Metachronous tumours were defined as new tumours arising in the colon at least six months after the initial diagnosis.[19] Semiquantitative assessment defined two subgroups, according to mucinous content of the tumour: $>50 \%$ of tumour area involved (mucinous) and 10 to $50 \%$ of tumour area involved. Mucinous adenocarcinomas and signet-ring cell carcinoma by convention were considered poorly differentiated [18], although are also separately scored. A Crohn's-like reaction was assessed as grade $0,1+$, or $2+$.[20] Grade 2+ was referred to as conspicuous. Leukocyte infiltration was assessed semi-quantitatively on H\&Eslides as none, moderate (visible only on high magnification $(\times 40)$, or marked (visible already on low magnification $\times 10$ ). 


\section{Molecular analysis}

Genomic DNA of paired normal colon and colorectal carcinoma tissue was isolated from formalin-fixed paraffinembedded material, as described previously.[21] The percentage of tumour cells in the areas from which the punches were taken, were in all cases above 50\% and in most cases above 70\%. Microsatellite instability analysis was done according to the Bethesda guidelines using the markers D2S123, D5S346, D17S250, BAT25, BAT26, and BAT40. A tumour was scored MS-stable when no marker showed instability, MSI-high when $>30 \%$ of markers showed instability, and MSI-low when only one marker $(<30 \%)$ showed instability.[22] For somatic mutation analysis of APC, KRAS2, p53 and SMAD4 DNA sequence analysis was performed. Codon 12 and 13 of the KRAS2 gene and the Mutation Cluster Region (codons 1286-1513) of the APC gene were analyzed as described previously. [23] Primer pairs were designed for the coding regions and exon-intron boundaries of $p 53$ exons 5-8 and SMAD4 exons 3-13. Primer details are available from the authors upon request. Germline DNA mutation analysis of the whole MUTYH gene was performed on lymphocytic DNA or DNA from formalin-fixed paraffin-embedded normal tissue as described previously. [3,5] Primer details are available from the authors upon request. For further details see the website of our DNA diagnostic laboratory [24]. To describe MUTYH mutations we used the most upto-date annotation, see the LOVD database.[25,26]

\section{Immunohistochemical analysis using tissue microarray}

To construct a tissue microarray (TMA), triplicate tissue cores were taken from tumour tissue as described previously [27] on the basis of H\&E-stained slides reviewed by a pathologist (HM).) Sections were deparaffinised and endogenous peroxidases were inactivated with $0.3 \%$ $\mathrm{H}_{2} \mathrm{O}_{2}$ in methanol solution after antigen retrieval by means of microwave oven treatment for 10 minutes in 10 mM citrate buffer pH 6.0 (p53, MLH1) or 1 mM TrisEDTA pH 8.0 (beta-catenin, PMS2). Sections were incubated overnight at room temperature with mouse antihuman monoclonal antibodies directed against p53 (clone D0-7, 1:1000, Neomarkers, USA), MLH1 (clone G168-728, 1:50, BD Pharmigen, USA), PMS2 (clone A164, 1:200, BD Pharmigen) and beta-catenin (encoded by CTNNB1) (clone 14, 1: 800, BD Transduction Laboratories, USA). The following day, tissue sections were incubated with a biotinylated secondary antibody in PBS/BSA $1 \%$. Diaminobenzidine tetrahydrochloride was used as a chromogen for the development of the staining. The slides were counterstained with hematoxylin. Immunohistochemistry (IHC) was scored for p53 nuclear staining as: $1=$ none, $2=>0<25 \%$ (mostly indicative of a functional intact p53 status), $3=25 \%-75 \%$, or $4=>75 \%$ (the latter two indicative of p53 dysfunction). Staining of betacatenin was graded by the following scale: $1=$ membra- nous staining, $2 \mathrm{~A}=$ membranous and some nuclear staining, $2 \mathrm{~B}=$ membranous staining, and increased nuclear staining, 3 = strong nuclear staining, with less or no membranous staining. Normal epithelium and stromal cells provided positive internal controls.

\section{Infiltrate analysis using fluorescent immunohistochemical staining}

Fluorescent immunostaining was performed as previously described.[28] Five $\mu \mathrm{m}$ TMA sections were used in all experiments. A mixture of the antibodies ab828 (rabbit polyclonal, anti-CD3; Abcam, UK), hNK-1 (mouse monoclonal IgM, anti-CD57; Department of Pathology, LUMC, The Netherlands), and 4B11 (mouse monoclonal IgG2b, anti-CD8; Novo Castra, UK) was added to each slide. The next day slides were incubated with the appropriate combination of fluorescent antibody conjugates (IgG-Alexa Fluor 546, IgM-Alexa Fluor 488 and IgG2bAlexa Fluor 647). Alexa Fluor conjugates were obtained from Molecular Probes (Leiden, the Netherlands). The images were captured with a confocal laser scanning microscope (LSM) (Zeiss LSM510, Zeiss, Germany). The number of each leukocyte sub-type was assessed per tumour area (TILs/ $\mathrm{mm}^{2}$ tumour epithelium) using the LSM software (Zeiss). Cells staining for CD3, and not for CD8 or other CD markers, were considered to be T-helper lymphocytes. Standard immunostaining for the associated cytotoxic molecule granzyme B (NCL-GRAN-B; clone $11 \mathrm{~F} 1$; Novo Castra) was performed in sequential sections. To calculate the density of granzyme $\mathrm{B}$ positive cells we used the assessed tumour area from the fluorescent immunostaining.

\section{Literature on histological and molecular features of CRC}

We compared literature available, describing histological and molecular features, on sporadic, MSI-high and Lynch CRCs. The following terms were employed as search terms: colon carcinomas, bowel cancer, CRC, sporadic, MSI-high, Lynch, HNPCC, histological, molecular, APC, KRAS2, p53, beta-catenin, CTNNB1, SMAD4, tumour infiltrating lymphocytes, tumour infiltrating lymphocytes and intra-epithelial lymphocytes. All relevant references within articles were identified and included.

\section{Statistical Analysis}

Fisher exact test was used to estimate an association between molecular and clinical-pathological parameters. The Spearman test was used to assess correlations. All Pvalues are reported for a two-tailed test; $P$-values of less than 0.05 were considered to be statistically significant. A group with high and low intraepithelial leukocyte infiltration was distinguished, using the median value as cutpoint of the leukocyte-infiltration scores of all patients. When a patient had more than one carcinoma the mean number of lymphocytes in these carcinomas was used for 
the survival analysis. The Kaplan-Meier method was used to calculate the overall survival and the log-rank test was used for comparison of the survival curves. All statistical analyses were carried out using the SPSS software package (SPSS Inc. 12.0, USA).

\section{Results \\ Histopathology of MAP carcinomas}

Forty-four MAP patients were diagnosed with 58 CRCs (see Table 1) at a mean age of 49 years (Table 2 and 3 ). Ten patients $(23 \%)$ had metachronous or synchronous carcinomas. The majority of carcinomas (35/51, 69\%, metachronous tumours not included), were right-sided, i.e. proximal to the flexura lienalis. The majority of proximal tumours were located in ascending colon or cecum $(80 \%, 28 / 35)$ and only a minority occurred in the transverse colon or hepatic flexure $(14 \%, 5 / 35)$. Fifty-five percent (29/53) were stage B according to MAC guidelines or T>1N0M0 according to the TNM guidelines. Forty-two colon carcinomas from 35 MAP index patients were available for further study (Table 1). Histological analysis showed poor differentiation in 26\% (11/42) and moderate in $71 \%$ (30/42, Figure 1A), mucinous CRCs represented $81 \%$ of these cases (9/11, Figure 1B). No MAP carcinomas showed a solid or medullary histotype or contained signet ring cells. A Crohn's like infiltrate was present in 33\% (13/40, Figure 1C). In 40\% (16/40) of tumours, focal necrosis (dirty necrosis within glandular lumina) was present. Tumour infiltrating lymphocytes assessed on H\&E-slides were present in 74\% (31/42) and were marked in 17\% (7/42, Figure 1D). In 33 tumours MSI status was analyzed and all carcinomas but one were MS-stable. The latter carcinoma showed instability of less than $30 \%$ of markers (one dinucleotide marker) designating the tumour as MSI-low. Furthermore, staining for MLH1 and PMS2 was positive for all the tumours.

No significant geno-phenotype correlations for any of the main histopathological parameters could be found.

\section{Somatic mutation analysis and immunohistochemical staining}

APC mutation analysis (Table 4 ) of the mutation cluster region showed somatic mutations in 5/36 (14\%) carcinomas; four were MUTYH associated transversions ( $\mathrm{G}>\mathrm{T}$ 's); two were $\mathrm{C}>\mathrm{T}$ transitions, one of them occurring together with a $\mathrm{G}>\mathrm{A}$ transition (patient 6 ). KRAS2 mutations were found in 23/36 (64\%) of tumours, 22 were c.34G>T transversions. An increased nuclear and reduced membranous beta-catenin staining was found in 11\% (4/35). In 57\% (20/35) of MAP CRCs, p53 staining indicative of a functional p53 status ( $>0<25 \%$ nuclear staining) was found. Nuclear staining indicative of p53 dysfunction was found in $34 \%(12 / 35)$ (Figure 1E). In 9 out of 16 carcinomas (56\%) that could be analyzed, ten $p 53$ mutations were found. One carcinoma had two mutations (patient 7, Table 4). Three mutations were $\mathrm{G}>\mathrm{T}$ transversions. Except in one case (patient 7, Table 4), staining was in concordance with the combined results of the p53 staining and LOH of chromosome $17 \mathrm{p}$ results published previously by Middeldorp et al (Table 4).[13] When staining was indicative of a dysfunctional p53 status, a mutation as well as LOH was found (patients 2, 23, 24, and 41). In cases were a mutation is present but no $\mathrm{LOH}$ was identified for $17 \mathrm{p}$, staining was indicative of a still intact, functional p53 (patient 5, 8, and 16). Only one case (patient 22) had a nonsense mutation in p53, explaining the absence of nuclear staining. All other p53 mutations are (probable pathogenic) amino acid substitutions and all except one have been published previously [29](Table 4). SMAD4 mutations were present in $26 \%$ of MAP carcinomas tested (5/19, Table 4). Two tumours had G>T tranversions.

\section{Infiltrate analysis}

First, we scored the presence of TILs and Crohn's like infiltrate on standard H\&E sections. Secondly, in order to establish an objective lymphocytic cell count, we also performed triple-fluorescent IHC staining for $\mathrm{CD}^{+}, \mathrm{CD}^{+}$, and CD57+ TILs (Figure 1F). The median number of intraepithelial T-helper (CD3+, CD8-), cytotoxic T lymphocyte (CTL, CD8+, CD57-) and natural killer cells (NK, CD8+/ $\mathrm{CD}^{2} 7^{+}$) found in 34 CRCs available for analyses were 20, 37 , and 0 cells $/ \mathrm{mm}^{2}$ tumour, respectively. There was a significant correlation between the total number of immunofluorescently detected TILs and the amount of TILs (none, present, marked) assessed on H\&E slides (Spearman's test, $P=0.002)$. Immunohistochemistry for granzyme B, which is expressed on activated CD8+ cytotoxic lymphocytes (CTLs) and involved in the induction of apoptosis of target cells, showed a median of 4 granzyme $\mathrm{B}^{+}$cells $/ \mathrm{mm}^{2}$. The number of CD8+ TILs showed a significant positive correlation with the number of granzyme $\mathrm{B}^{+}$cells (Spearman's test, $P=0.009$ ). No significant differences in survival were seen between patients with high versus low levels of TILs, although in patients with a high level of CD8+ TILs and granzyme $\mathrm{B}^{+}$cells, a tendency was observed towards a better prognosis (Figure $2 \mathrm{~A}$ and $2 \mathrm{~B}, P=0.15$ and $P=0.2$, respectively, log rank test).

\section{Literature Review}

Results are shown in Table 2 and 3; different study outcomes were aggregated in Table 2 and Table 3 shows concise conclusions of these data. Data on Lynch syndrome carcinomas only included proven mismatch repair gene mutation carriers. An extended version of Table 2 is available online, as a supplement (Additional file 1), showing outcomes of all the individual articles and including data for Lynch syndrome suspected carcinomas where no 


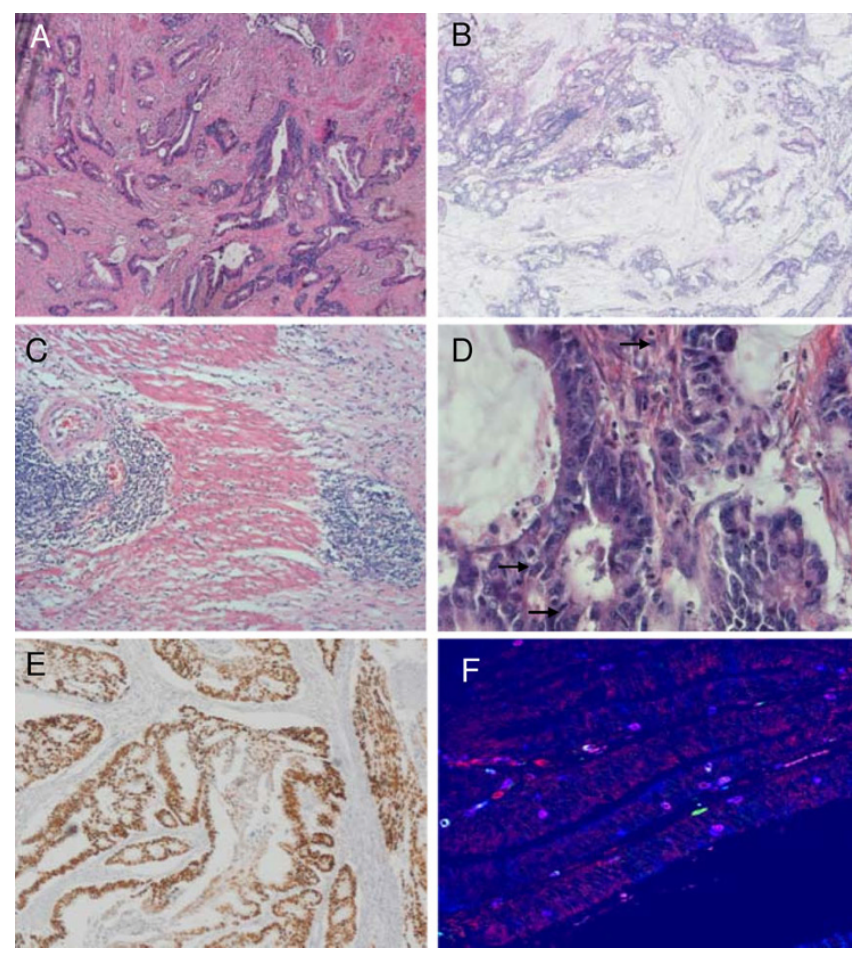

\section{Figure I}

MAP CRC histology. A) moderate differentiation, tumour $23,5 \times$ B) $>50 \%$ mucinous, tumour 29, $5 \times$ C) Crohn's like infiltrate, tumour 34, 5× D) TILs, tumour 33, 40× E) p53 staining, $>75 \%$ nuclear staining, tumour $32,5 \times \mathrm{F}$ ) CD3/CD8/ CD57 immunofluorescent staining, tumour 35 , red cells: $\mathrm{CD}^{+}$, purple cells: $\mathrm{CD}^{+} \mathrm{CD}^{+}$, white cells: $\mathrm{CD}^{+} \mathrm{CD}^{+}$ $\mathrm{CD}^{2} 7^{+}, 40 \times$.

germline mutations in the mismatch repair genes were searched for or found.

\section{Discussion}

Specific histological and molecular characterization of CRCs may have implications in the diagnosis, prognosis, and treatment strategies, as demonstrated for mismatch repair deficient MSI-high CRCs.[15,16,30] In order to explore similar implications for MAP, we analyzed clinical, histological and molecular pathologic characteristics in our series of MAP CRCs and compared our findings to the literature (Table 2 and 3). Age at diagnosis of CRC, when compared to sporadic cases, was relatively young in MAP patients and comparable to that in Lynch patients (49 and 47 years). MAP CRCs showed less metastases than sporadic CRCs, but more than Lynch carcinomas (Table 2 and 3). A prominent feature is the 69\% proximal sublocalization of colon carcinomas in this cohort; others reported a proximal location in 29, 43 and 46\% of MAP CRCs. $[4,11,31]$ This is still more than that reported in sporadic carcinomas (23\%) but less than MSI-high or Lynch carcinomas (75\% and 67\% respectively, Table 2 and 3). Furthermore, this study showed that proximal MAP tumours had a preferential location in the cecum or ascending colon, as opposed to the transverse colon, which was also reported by O'Shea at al.[31]

The relatively high number of observed (meta) synchronous carcinomas in MAP patients is in agreement with previous reports on MAP patients (Table 2). In contrast to sporadic carcinomas but in agreement with MSI-high carcinomas, MAP CRC's were demonstrated to be relatively often mucinous in this study (Table 2). O'Shea et al. found a poor (low) differentiation grade in all MAP carcinomas $(16 / 16)$ but remarkably, none had a mucinous pattern $(0 / 16) \cdot[31]$

In MSI-high tumours the caretaker function of mismatch repair enzymes is disrupted resulting in somatic mutations that are accumulated throughout the cell genome. Such abundance of mutations can result in aberrant frameshift peptides that would be presented at the cell surface, through the antigen processing pathway, to cells of the immune system. This sequence of events could explain the presence of an accentuated intra-epithelial lymphocytic infiltrate in MSI-high tumours.[14,32,33] In MAP carcinomas the disruption of the caretaker function of the BER machinery, mediated by MUTYH mutations, leads to the accumulation of $\mathrm{G}>\mathrm{T}$ somatic mutations, at least early in tumourigenesis, which might evoke similar specific anti-tumour immune responses. TILs were present in a majority of MAP CRCs (74\%) in this study, although marked infiltration was only detected in about one fifth of MAP carcinomas. The median number of $\mathrm{CD}^{+}$lymphocytes in MAP CRCs, scored with IHC, fell somewhere between that found in MSI-stable and MSI-high CRC's (indicated by absent MLH-1 expression) previously analyzed with the same procedure in our laboratory.[34] O'Shea et al. reported the same percentage of TILs present in MAP CRCs as in their controls (50\%, 8/16).[31] Their controls, however, might not be representative of sporadic CRCs, as the number of TILs reported by others in sporadic CRCs is much less (24\%, Table 2 and 3). In MSI-high tumours, an active immune response by the host (represented by a high number of TILs) was also associated with a better survival, especially when associated with granzyme B positivity.[33] The group of MAP patients with a high number of $\mathrm{CD}^{+}$and granzyme $\mathrm{B}^{+}$TILs showed a better overall survival, although not statistically significant for either parameters.

The number of APC mutations in the mutation cluster region found in MAP carcinomas (14\%) is notably lower than that reported in sporadic CRCs (63\%, Table 2 and 3$)$. One possible explanation for the relatively small number of APC mutations could be that in MAP CRCs more mutations lay outside the mutation cluster region. In sporadic 
Table I: MAP patients and histological features of colorectal carcinomas

\begin{tabular}{|c|c|c|c|c|c|c|c|c|c|c|c|c|c|}
\hline TumourNr & $\begin{array}{l}\text { Fam } \\
\mathrm{nr}\end{array}$ & $\begin{array}{l}\text { MUTYH } \\
\text { Mut Ia }\end{array}$ & $\begin{array}{l}\text { MUTYH } \\
\text { Mut } 2\end{array}$ & Loc CRC & Age CRC & TNM stage & $\begin{array}{l}\text { MAC } \\
\text { stagef }\end{array}$ & $\begin{array}{l}\text { Differentiati } \\
\text { ontt }\end{array}$ & Mucinous & $\begin{array}{l}\text { Chrohn's like } \\
\text { infiltrate* }\end{array}$ & TILs** & $\begin{array}{l}\text { Nec- } \\
\text { rosis }\end{array}$ & $\begin{array}{l}\text { Remarks/ } \\
\text { other cancers }\end{array}$ \\
\hline I & 61883.1 & p.R247X & p.P405L & C & 48 & T4NOMO & B3 & mod & No & 1 & no & yes & \\
\hline 2 & 19036.2 & p.YI79C & p.YI79C & C & 41 & $\mathrm{~T} 2 \mathrm{~N} 2 \mathrm{MI}$ & $D$ & $\bmod$ & No & 0 & no & no & \\
\hline 3 & & & & C & 41 & $\mathrm{~T} 2 \mathrm{~N} 2 \mathrm{MI}$ & $\mathrm{D}$ & $\bmod$ & No & 2 & no & no & \\
\hline 4 & & & & $R / S$ & 41 & $\mathrm{~T} 2 \mathrm{~N} 2 \mathrm{MI}$ & $\mathrm{D}$ & muc & yes, $>50 \%$ & 1 & no & no & \\
\hline 5 & & & & $A C$ & 41 & T2N2MI & $D$ & muc & yes, $>50 \%$ & 1 & no & yes & \\
\hline 6 & 19049.1 & p.YI79Cb & p.YI79C & SF & 56 & T3NOMO & B2 & & & & & & $\begin{array}{l}\text { Laryngeal carc. } \\
\text { age } 57\end{array}$ \\
\hline 7 & & & & $\mathrm{R}$ & 69 & T3NOMO & B2 & $\bmod$ & No & 2 & + & no & $\begin{array}{l}\text { Urothelial carc. } \\
\text { age } 67\end{array}$ \\
\hline 8 & 19049.2 & p.YI79C & p.YI79C & $A C$ & 53 & T3NOMO & B2 & mod & yes, $<50 \%$ & 2 & ++ & no & \\
\hline 9 & 19053.4 & p.YI79Cb & $\begin{array}{l}c .933+3 A> \\
C\end{array}$ & $A C$ & 51 & T3NOMO & B2 & $\bmod$ & No & 0 & + & yes & \\
\hline 10 & 19053.2 & p.YI79Cb & $\begin{array}{l}c .933+3 A> \\
C\end{array}$ & C & 53 & T3NOMO & B2 & mod & No & 2 & + & yes & \\
\hline II & 19221.1 & p.YI79C & p.P405L & C & 56 & T3NOMO & B2 & muc & yes, $>50 \%$ & 0 & + & yes & $\begin{array}{l}\text { Duodenal carc } \\
\text { age } 56\end{array}$ \\
\hline 12 & 20090.1 & p.YI79C & p.P405L & $A C$ & 50 & T3NOMO & B2 & mod & yes, $<50 \%$ & 2 & ++ & yes & $\begin{array}{l}\text { Exol mutation } \\
\text { IVSI2-I G>C } \\
\text { (Jagmohan et al.) }\end{array}$ \\
\hline 13 & 20090.6 & p.YI79C & p.P405L & $R / S$ & 39 & T3NOMI & $D$ & poor & No & 0 & no & yes & $\begin{array}{l}\text { Exol mut. } \\
\text { IVSI2-IG>C }\end{array}$ \\
\hline 14 & 52240.1 & p.P405L & p.P405L & $\mathrm{R}$ & 58 & T3NOMO & B2 & muc & yes, $>50 \%$ & 0 & + & no & $\begin{array}{l}\text { Breast carc age } \\
54\end{array}$ \\
\hline 15 & 52596.1 & p.YI79C & p.YI79C & C & 44 & T3N0M0 & B & muc & yes, $>50 \%$ & 2 & ++ & yes & \\
\hline 16 & 52654.1 & p.P405L & p.P405L & $A C$ & 37 & TIN2M0 & $\mathrm{Cl}$ & $\bmod$ & No & 2 & + & no & \\
\hline 17 & & & & $A C$ & 37 & $\mathrm{~T} 2 \mathrm{~N} 2 \mathrm{M} 0$ & $\mathrm{Cl}$ & $\bmod$ & No & & + & no & \\
\hline 18 & 53029.1 & p.YI79Cb & p.P405L & C & 41 & T3N2M0 & $\mathrm{C} 2$ & mod & No & 1 & + & no & \\
\hline
\end{tabular}




\begin{tabular}{|c|c|c|c|c|c|c|c|c|c|c|c|c|c|}
\hline 19 & 53231.1 & p.G396D & p.G396D & $\overline{A C}$ & 59 & T2N0M0 & $\mathrm{BI}$ & $\bmod$ & No & 0 & + & yes & \\
\hline 20 & 54092.2 & p.G396Db & p.G396D & C & 60 & T2NOMO & BI & $\bmod$ & No & 1 & + & no & \\
\hline 21 & 54178.1 & p.G396D & p.P405L & $S$ & 44 & T3NOMO & B2 & muc & yes, $>50 \%$ & 2 & no & no & \\
\hline 22 & $54 \mid 86.1$ & p.YI79C & p.YI79C & $A C$ & 45 & T4NxMI & $\mathrm{D}$ & $\bmod$ & No & 0 & + & no & $\begin{array}{l}\text { Basal cell carc. } \\
\text { age } 42\end{array}$ \\
\hline 23 & 54186.6 & p.YI79Cb & p.YI79C & $S$ & 43 & T3N0M0 & B2 & $\bmod$ & No & 0 & no & no & \\
\hline 24 & & & & $\mathrm{HF}$ & 43 & T3NOMO & B2 & $\bmod$ & yes, $<50 \%$ & 1 & + & no & \\
\hline 25 & 54245.1 & p.YI79C & p.YI79C & $\mathrm{R}$ & 54 & & & & & & & & $\begin{array}{l}\text { Breast carc age } \\
77 \& 79\end{array}$ \\
\hline 26 & & & & 'left' & 57 & & & & & & & & $\begin{array}{l}\text { Basal cell carc. } \\
\text { age } 53\end{array}$ \\
\hline
\end{tabular}

\begin{tabular}{|c|c|c|c|c|c|c|c|c|c|c|c|c|c|}
\hline 27 & & & & 1 & 77 & & & & & & & & \\
\hline 28 & & & & $A C$ & 77 & T3NOMO & B2 & $\bmod$ & yes, $<50 \%$ & 1 & + & no & \\
\hline 29 & 54962.10 & p.G396D b & p.P405L & $A C$ & 51 & T2NIMO & $\mathrm{Cl}$ & muc & yes, $>50 \%$ & 0 & ++ & no & \\
\hline 30 & 55247.1 & p.YI79C & p.R247X & C & 46 & T2NOMO & $\mathrm{BI}$ & muc & yes, $>50 \%$ & 2 & ++ & yes & \\
\hline 31 & 55535.1 & p.YI79C & p.YI79C & C & 45 & T3N2MI & $\mathrm{D}$ & $\bmod$ & yes, $<50 \%$ & 2 & + & yes & \\
\hline 32 & 56081.1 & p.YI79C & p.G396D & $\mathrm{HF}$ & 59 & T3NOMO & B2 & $\bmod$ & No & 2 & no & yes & \\
\hline 33 & 56081.2 & p.YI79Cb & p.G396D & $A C$ & 49 & T3NIMO & $\mathrm{C} 2$ & $\bmod$ & yes, $<50 \%$ & 2 & ++ & yes & \\
\hline 34 & 56566.1 & p.YI79C & p.G396D & $\mathrm{TC}$ & 67 & T3NIM0 & $\mathrm{C} 2$ & $\bmod$ & No & I & + & yes & \\
\hline 35 & $5664 I .1$ & p.YI79C & p.G396D & C & 43 & T3NOMO & B2 & $\bmod$ & yes, $<50 \%$ & 2 & + & no & \\
\hline 36 & & & & $\mathrm{TC}$ & 46 & T3N0M0 & B2 & mod & No & 1 & + & no & \\
\hline 37 & $57 \mid 39.1$ & c.II45delc & p.G396D & $S$ & 42 & T2NOMO & B & $\bmod$ & No & 1 & no & no & \\
\hline 38 & & & & $S$ & 42 & TINOMO & A & $\bmod$ & yes, $<50 \%$ & & + & no & \\
\hline 39 & 57246.1 & p.YI79C & p.YI79C & C & 65 & T2NOMO & BI & $\bmod$ & yes, $<50 \%$ & 0 & + & no & $\begin{array}{l}\text { Duodenal carc } \\
\text { age } 64\end{array}$ \\
\hline 40 & & & & $A C$ & 65 & T2NOMO & BI & well & No & 0 & ++ & no & \\
\hline
\end{tabular}


Table I: MAP patients and histological features of colorectal carcinomas (Continued)

\begin{tabular}{|c|c|c|c|c|c|c|c|c|c|c|c|c|c|}
\hline 41 & 57249.1 & p.YI79C & p.YI79C & $R / S$ & 49 & T3NOMO & B2 & mod-poor & No & $T$ & + & & $\begin{array}{l}\text { Esophageal carc. } \\
\text { (Barret) age } 59\end{array}$ \\
\hline 42 & 57249.13 & p.YI79Cb & p.YI79C & $R$ & 52 & T2NOMO & BI & $\bmod$ & No & 0 & + & & \\
\hline 43 & 57249.9 & p.YI79C & p.YI79C & C & 49 & T2NIMO & $\mathrm{Cl}$ & $\bmod$ & No & I & no & no & \\
\hline 44 & 60322.4 & p.YI79C & p.G396D & 'right' & 39 & T4NIM0 & $\mathrm{C} 3$ & $\bmod$ & No & 0 & + & yes & \\
\hline 45 & 52638.4 & P.G396Db & p.RI09W & $C$ & 52 & T3NOMI & $D$ & poor & No & I & + & yes & \\
\hline 46 & 57449.1 & p.YI79C & p.YI79C & HF & 45 & T3NOMO & B2 & muc & yes, $>50 \%$ & 0 & + & no & $\begin{array}{l}2^{\text {nd }} \\
\text { carc.(rectum) } \\
\text { age } 69\end{array}$ \\
\hline
\end{tabular}

\begin{tabular}{|c|c|c|c|c|c|c|c|c|}
\hline 47 & 19047.I & p.G396D & p.G396D & 'right' & 70 & TxNIMO & C & \\
\hline 48 & 19106.1 & p.YI79C & p.YI79C & $\mathrm{R}$ & 40 & TxNOMO & B & \\
\hline 49 & 57591.1 & p.P405L & p.YI79C & C & 40 & TxNIMI & $D$ & \\
\hline 50 & 60406.1 & p.E480del & p.E480del & $A C$ & 51 & T3NOMO & B2 & \\
\hline 51 & 51063.1 & p.YI79C & p.YI79C & SF & 44 & TINOMO & A & \\
\hline 52 & $54 \mid 40.1$ & p.E4IOfs & p.E4IOfs & $\mathrm{R}$ & 42 & TxNOMO & B & $\begin{array}{l}\text { Cervical carc. } \\
\text { age } 27\end{array}$ \\
\hline 53 & $57 \mid 35.1$ & p.YI79C & p.YI79C & $\mathrm{HF}$ & 46 & TxNIMI & $\mathrm{D}$ & \\
\hline 54 & 55356.1 & c.1145delc & p.P405L & $R$ & 42 & TxNOMO & B & \\
\hline 55 & 53276.1 & p.G396D & p.P405L & C & 48 & TINOMO & A & $\begin{array}{l}\text { Basal cell carc. } \\
\text { age } 58\end{array}$ \\
\hline 56 & 19247.3 & p.YI79Cb & p.YI79C & $R$ & 43 & & & $\begin{array}{l}\text { CRC metastasis } \\
\text { age } 63\end{array}$ \\
\hline
\end{tabular}

\begin{tabular}{lllll}
\hline 57 & 'right' & 53 & TxNIMI & D \\
\hline 58 & 'right' & 59 & & \\
\hline
\end{tabular}

Blank cells: not done/not ascertainable, $\mathrm{CRC}=$ colorectal cancer, $\mathrm{R}=$ rectum, $\mathrm{S}=$ sigmoid colon, $\mathrm{DC}=$ descending colon, $\mathrm{SF}=\mathrm{splenic}$ flexure, $\mathrm{TC}=$ transverse colon, $\mathrm{HF}=$ hepatic flexure, $\mathrm{AC}=$ ascending colon, $\mathrm{C}=$ cecum, I = ileum.

aAccording to the recently changed MUTYH Nomenclature (Human Genome Variation Society), adding 14 amino acids after amino acid position 53. For example: YI65C $>$ Y I79C and

G382D $>$ G396D, banalysis in DNA from FFPE material. †MAC $=$ Modified Astler-Coller, t†mod $=$ moderate, muc $=$ mucinous, $* 0=$ none, $I=$ mild reaction, $2=$ intense reaction (conspicuous) $* *$ tumour infiltrating lymfocytes $0=$ none/few,$+=$ moderate, $++=$ marked, $\sim$ yes $=$ focal necrosis (dirty necrosis within glandular lumina). 
Table 2: Histological and molecular features of carcinomas

\begin{tabular}{|c|c|c|c|c|c|}
\hline $\begin{array}{l}\text { Characteristics } \\
\text { Colon carcinomas }\end{array}$ & & MAP & Sporadic CRC & Sporadic MSI-high & $\begin{array}{l}\text { Lynch } \\
\text { (based on MMR } \\
\text { mutations) }\end{array}$ \\
\hline Average age at CRC & & $\begin{array}{l}49 \text { years }[C S] \\
59 \text { years } 11\end{array}$ & 68 years & $67-75$ years & 47 years \\
\hline TNM stage & III or IV & $\begin{array}{l}34 \%(51 / 148) \\
55 \%(10 / 18)[1]\end{array}$ & $42 \%(|78| / 4 \mid 93)$ & $43 \%(19 / 44)$ & $15 \%(15 / 101)$ \\
\hline Proximal location & & $\begin{array}{l}69 \%(35 / 51)[C S] \\
29 \%(7 / 24)^{11} \\
43 \%(16 / 37)^{4} \\
46 \%(6 / 13)^{31}\end{array}$ & $23 \%(1887 / 8 \mid 29)$ & $75 \%(308 / 4 I I)$ & $67 \%(74 / I I I)$ \\
\hline $\begin{array}{l}\text { (Meta) synchronous } \\
\text { CRC }\end{array}$ & & $\begin{array}{l}23 \%(10 / 44)[C S] \\
33 \%(6 / 18)^{\prime \prime} \\
26 \%(8 / 29)^{4}\end{array}$ & $2 \%(14 / 832)$ & & $18 \%(7 / 38)$ \\
\hline Poor Differentiation & & $\begin{array}{l}26 \%(11 / 42)[C S] \\
22 \%(5 / 23)^{11} \\
100 \%(16 / 16)^{31}\end{array}$ & $10 \%(765 / 7590)$ & $41 \%(203 / 50 I)$ & $38 \%(38 / 101)$ \\
\hline Mucinous & $(>50 \%)$ & $\begin{array}{l}21 \%(9 / 42)[C S] \\
13 \%(3 / 23)^{11} \\
0 \%(0 / 16)^{31}\end{array}$ & $12 \%(292 / 2480)$ & $28 \%(104 / 376)$ & $35 \%(40 / 113)$ \\
\hline $\begin{array}{l}\text { Crohn's like } \\
\text { infiltrate }\end{array}$ & Conspicuous & $\begin{array}{l}33 \%(13 / 40)[C S] \\
31 \%(5 / 16)^{31}\end{array}$ & $28 \%(586 / 2059)$ & $54 \%(318 / 589)$ & $49 \%(37 / 76)$ \\
\hline Necrosis & & $40 \%(16 / 40)[C S]$ & $77 \%(356 / 465)$ & $17 \%(9 / 52)$ & \\
\hline \multirow[t]{2}{*}{ TILs* } & $\begin{array}{l}\text { Present } \\
\text { (moderate and marked) }\end{array}$ & $\begin{array}{l}74 \%(31 / 42)[C S] \\
50 \%(8 / 16)^{31}\end{array}$ & $24 \%(338 / / 406)$ & $58 \%(155 / 268)$ & $33 \%(4 / 12)$ \\
\hline & Marked & $17 \%(7 / 42)[C S]$ & $4 \%(34 / 889)$ & $29 \%(63 / 218)$ & $17 \%(2 / 12)$ \\
\hline$A P C$ & $\begin{array}{l}\text { Mutations ( }+M C R \text {, } \ddagger \text { also } \\
\text { outside the MCR) }\end{array}$ & $\begin{array}{l}14 \%(5 / 36)[C S] \dagger \\
43 \%(6 / 14)^{11 \ddagger} \\
83 \%(5 / 6)^{31 \dagger}\end{array}$ & $\begin{array}{l}63 \%(459 / 724)^{\dagger *} \\
52 \%(281 / 539)^{\ddagger}\end{array}$ & $\begin{array}{l}5 \%(1 / 21)^{\dagger} \\
41 \%(56 / 136)^{\ddagger}\end{array}$ & $33 \%(6 / 18)^{\ddagger}$ \\
\hline KRAS & Mutations codon $12 / 13$ & $\begin{array}{l}64 \%(23 / 36)[C S] \\
64 \%(9 / 14)^{11}\end{array}$ & $29 \%(1090 / 3710)$ & $20 \%(56 / 280)$ & $34 \%(91 / 267)$ \\
\hline \multirow[t]{2}{*}{$\begin{array}{l}\text { Beta-catenin } \\
\text { (CTNNBI) }\end{array}$} & Nuclear staining & $\begin{array}{l}11 \%(4 / 35)[C S] \\
71 \%(12 / 17)^{11}\end{array}$ & $77 \%(138 / 179)$ & $13 \%(4 / 3 \mid)$ & $59 \%(40 / 68)$ \\
\hline & Mutations & $0 \%(0 / 16)^{5}$ & $5 \%(30 / 610)$ & $7 \%(2 / 27)$ & $20 \%(11 / 56)$ \\
\hline \multirow[t]{2}{*}{ P53 } & $\begin{array}{l}\text { Nuclear staining } \\
>25 \%\end{array}$ & $\begin{array}{l}34 \%(12 / 35)[C S] \\
53 \%(8 / 15)^{11}\end{array}$ & $57 \%(668 / 1167)$ & $15 \%(20 / 130)$ & $72 \%(23 / 32)$ \\
\hline & Mutations & $\begin{array}{l}60 \%(9 / 15)[C S] \\
21 \%(3 / 14)^{11}\end{array}$ & $43 \%(1808 / 4299)$ & $22 \%(21 / 95)$ & $22 \%(2 / 9)$ \\
\hline SMAD4 & Mutations & $\begin{array}{l}26 \%(5 / 19)[C S] \\
0 \%(0 / 14)^{11}\end{array}$ & $22 \%(17 / 77)$ & & $18 \%(2 / 11)$ \\
\hline MSI & High & $\begin{array}{l}0 \%(0 / 33)[C S] \\
0 \%(0 / 17)^{11} \\
18 \%(2 / 11)^{31} \\
33 \%(1 / 3)^{43}\end{array}$ & $12 \%(227 / \mid 834)$ & & $90 \%(88 / 98)$ \\
\hline
\end{tabular}

$\mathrm{CS}=$ current study, MAP = MUTYH-associated polyposis, MSS= microsatellite stable, MSI = microsatellite instability, TIL = Tumour Infiltrating Lymphocytes, $\mathrm{MCR}=$ mutation cluster region. *Relative large proportion of missense mutations $(29 \%)$ in study by Luchtenborg et al as compared to other studies, explaining the high overall percentage of APC mutations in the MCR only group. See Additional file I online for more details and article references. 
CRCs, APC mutations in the MCR represent $50-77 \%$ of all APC mutations found. [35-37] In MAP tumours (CRCs and adenomas), a substantial proportion ( $60 \%)$ of mutations were found outside the MCR.[10,11] Similarly, in MSI-high CRCs noticeably more APC mutations are found when larger regions of APC were analyzed (Table 2A). Another explanation might be that distal carcinomas, which are underrepresented in our cohort, have more APC mutations than proximal tumours as shown by Luchtenborg et al.[38] In addition, APC-MCR mutations were seen in $46 \%(13 / 28)$ of rectum carcinomas analyzed previously in our laboratory.[39]

In agreement with data derived on MSI-high carcinomas, strong beta-catenin nuclear staining was not frequent in MAP carcinomas in this study $(13 \%$ and $11 \%$, respec- tively). In sporadic CRCs this rate is much higher (77\%, Table 2 and 3 ).

We found a high percentage of KRAS2 mutations in our MAP CRCs (64\%), comparable to reports by Lipton et al. and Jones et al.[11,40] The vast majority (96\%) were c.34G $>$ T transversions (GGT>TGT). Intriguingly, no G>T transversions at the second nucleotide of this codon (leading to GGT> GTT) have been reported so far in MAP CRCs.

In contrast, KRAS2 mutations are found on average in $29 \%$ of sporadic CRCs and $22 \%$ of sporadic MSI-high carcinomas. Furthermore, the c.34G>T tranversion comprises just $8 \%$ of KRAS2 mutations in sporadic and none in MSI-high CRCs.[12] In Lynch carcinomas the percentage of KRAS2 mutations is around 34\%, Table 2 and 3)

Table 3: Concise overview of data in Table 2

\begin{tabular}{|c|c|c|c|c|}
\hline & MAP & Sporadic CRC & Sporadic MSI-high & Lynch (based on MMR mutations) \\
\hline Average age (years) & 49 & 68 & $67-75$ & 47 \\
\hline MAC stage $C$ or $D$ & + & ++ & ++ & + \\
\hline Proximal location & ++ & + & +++ & ++ \\
\hline (Meta) synchronous CRC & + & 0 & ND & + \\
\hline Poor Differentiation & + & 0 & + & + \\
\hline Mucinous (>50\%) & $+*$ & $+*$ & + & + \\
\hline Crohn's like infiltrate (conspicuous) & + & + & ++ & + \\
\hline Necrosis & + & ++ & + & ND \\
\hline TILs* present & ++ & + & ++ & + \\
\hline TILs marked & + & 0 & + & + \\
\hline APC-MCR mutations & + & ++ & + & + \\
\hline KRAS mutations (codon I/2/13) & ++ & + & + & + \\
\hline Beta-catenin (nuclear staining) & + & +++ & + & ++ \\
\hline Beta-catenin (CTNNBI) mutations & 0 & 0 & 0 & + \\
\hline P53 (nuclear staining $>25 \%$ ) & + & ++ & + & +++ \\
\hline P53 mutations & ++ & ++ & + & + \\
\hline SMAD4 mutations & + & + & 0 & + \\
\hline MSI-high & 0 & + & +++ & +++ \\
\hline
\end{tabular}

$0=0-10 \%,+=11-40 \%,++=41-70 \%,+++=>70 \%$ ND = no data

* mucinous rate in MAP CRCs in this study was two times more than in sporadic CRCs: $23 \%$ and $12 \%$ respectively (see also table 2 ). 
Table 4: Results of somatic mutation analysis and IHC analysis

\begin{tabular}{|c|c|c|c|c|c|c|c|c|c|}
\hline $\begin{array}{l}\text { Tumour } \\
n r\end{array}$ & $\begin{array}{l}\text { APC }(M C R) \\
\text { mutation* }\end{array}$ & $\begin{array}{l}\text { KRAS } \\
\text { mutation }\end{array}$ & $\begin{array}{l}\text { p53 } \\
\text { IHCt }\end{array}$ & p53 mutation* & $\begin{array}{l}\text { I7P } \\
\text { LOH@ }\end{array}$ & $\begin{array}{l}\text { Beta-catenin } \\
\text { IHCHt }\end{array}$ & SMAD4 mutation* & $M S / c$ & $\begin{array}{l}\text { MLHI-PMS2 } \\
I H C^{* *}\end{array}$ \\
\hline I & no & c.34G $>\mathrm{T}$ & ++ & No & yes & 0 & c.227G>GT, p.R76RI & S & + \\
\hline 2 & no & c.34G $>\mathrm{T}$ & +++ & $\begin{array}{l}\text { c. } 758 \mathrm{C}>\mathrm{CT}, \\
\text { p. }\left.\mathrm{T} 253 \mathrm{~T}\right|^{*}\end{array}$ & yes & 0 & no & S & + \\
\hline 3 & no & no & +++ & & yes & 0 & & S & + \\
\hline 4 & no & c. $34 \mathrm{G}>\mathrm{T}$ & + & & no & 0 & $\begin{array}{l}\text { c. } 1058 \mathrm{~A}>\mathrm{AG}, \\
\text { p.Y353YC* } \\
\text { c. } 1096 \mathrm{C}>\mathrm{CT}, \\
\text { p.Q366QX }\end{array}$ & $S$ & + \\
\hline 5 & no & c. $34 \mathrm{G}>\mathrm{T}$ & + & c.593A >AT, p.EI98EV & no & 0 & $\begin{array}{l}\text { c. } 16 \text { IT >TC, p.L54LS } \\
\text { c. } 740 \mathrm{G}>\mathrm{GA} \text {, } \\
\text { p.G247GE } \\
\text { c. } 1597 \mathrm{C}>\mathrm{CT} \text {, } \\
\text { p.L533LF }\end{array}$ & S & + \\
\hline 7 & $\begin{array}{l}\text { c. } 3949 \mathrm{G}>\mathrm{GT} \\
\text { p. EI3I7EX* } \\
\text { c. } 4339 \mathrm{C}>\mathrm{CT} \\
\text { p. Q } 1447 \mathrm{Q} X^{*}\end{array}$ & no & + & $\begin{array}{l}\text { c. } 565 G>G A \\
\text { p.A189AT* } \\
\text { c.599A>AG, } \\
\text { p.N200NS* }\end{array}$ & yes & $0 /+$ & no & $S$ & + \\
\hline 8 & no & c.34G > T & + & $\begin{array}{l}\text { c. } 446 C>C T, \\
\text { p.SI } 49 \mathrm{SF}^{*}\end{array}$ & no & 0 & no & $S$ & + \\
\hline II & no & no & 0 & & & 0 & & S & + \\
\hline 12 & no & no & + & & & 0 & & S & + \\
\hline 13 & no & c.34G $>\mathrm{T}$ & 0 & & & $+/++$ & & $\mathrm{L} \sim$ & heterogenous \\
\hline 14 & no & no & & No & no & & no & $\mathrm{S}$ & + \\
\hline 16 & no & c. $34 \mathrm{G}>\mathrm{T}$ & + & $\begin{array}{l}\text { c. } 446 C>C T, \\
\text { p.SI } 49 \mathrm{SF}^{*}\end{array}$ & no & + & $\begin{array}{l}\text { c. } 115 \mathrm{G}>\mathrm{GA}, \mathrm{p} . \mathrm{A} 39 \mathrm{AT} \\
\text { c.74G>GA, p.C25CY }\end{array}$ & $S$ & + \\
\hline 17 & no & c. $34 \mathrm{G}>\mathrm{T}$ & +++ & & no & 0 & $\begin{array}{l}\text { c. } 1609 \mathrm{G}>\mathrm{GT} \\
\text { p.D537DY* }\end{array}$ & & + \\
\hline 18 & no & no & + & & & 0 & & $S$ & \\
\hline 20 & no & c.34G $>\mathrm{T}$ & + & & & $0 /+$ & & $S$ & + \\
\hline 21 & $\begin{array}{l}\text { c. } 4222 \mathrm{G}>\mathrm{GT} \\
\text { p.EI408EX* }\end{array}$ & no & + & & & 0 & & $S$ & + \\
\hline 22 & $\begin{array}{l}\text { c. } 4222 \mathrm{G}>\mathrm{GT} \\
\text { p.EI408EX* }\end{array}$ & no & + & $\begin{array}{l}\text { c. }|379| \mathrm{G}>\mathrm{GT}, \\
\text { p.E27|EX* }\end{array}$ & yes & $0 /+$ & no & S & + \\
\hline 23 & no & c.34G $>\mathrm{T}$ & ++ & $\begin{array}{l}\text { c. } 596 \mathrm{G}>\mathrm{GT}, \\
\text { p.G199GV* }\end{array}$ & yes & 0 & no & S & + \\
\hline 24 & no & c.34G $>\mathrm{T}$ & ++ & $\begin{array}{l}\text { c. } 820 G>G T, \\
\text { p.V274VF* }\end{array}$ & yes & 0 & & $S$ & + \\
\hline 28 & no & c.34G $>T$ & + & No & & 0 & no & $S$ & + \\
\hline
\end{tabular}


Table 4: Results of somatic mutation analysis and IHC analysis (Continued)

\begin{tabular}{|c|c|c|c|c|c|c|c|c|c|}
\hline 29 & no & c.34G>T & 0 & & yes & $0 /+$ & no & $S$ & + \\
\hline 30 & no & c. $34 \mathrm{G}>\mathrm{T}$ & + & & & $0 /+$ & & $S$ & + \\
\hline 31 & $\begin{array}{l}\text { c. } 4085 C>C T \\
\text { p.SI } 362 S F\end{array}$ & no & + & & & ++ & & $S$ & + \\
\hline 32 & no & no & +++ & & no & + & no & $S$ & \\
\hline 33 & no & c. $34 \mathrm{G}>\mathrm{T}$ & ++ & & & $0 /+$ & & $S$ & \\
\hline 34 & no & no & +++ & No & yes & 0 & no & $S$ & + \\
\hline 35 & no & c.34G $>\mathrm{T}$ & + & No & no & 0 & & $S$ & + \\
\hline 36 & $\begin{array}{l}\text { c. } 438 \text { IG>GT } \\
\text { p.EI46IEX }\end{array}$ & c. $34 \mathrm{G}>\mathrm{T}$ & + & & no & $0 /+$ & no & $S$ & + \\
\hline 37 & no & c. $34 \mathrm{G}>\mathrm{T}$ & + & & yes & 0 & & $S$ & \\
\hline 38 & no & no & + & & no & $0 /+$ & & $S$ & + \\
\hline 39 & no & c. $34 \mathrm{G}>\mathrm{T}$ & + & & & 0 & & $S$ & + \\
\hline 40 & no & c. $34 G>T$ & + & & & 0 & & $S$ & + \\
\hline 41 & no & no & ++ & $\begin{array}{l}\text { c. } 13794 G>G A \\
\text { p.V272VM* }\end{array}$ & yes & 0 & no & $S$ & + \\
\hline 42 & no & c. $34 \mathrm{G}>\mathrm{A}$ & ++ & & & 0 & no & $S$ & + \\
\hline 43 & no & c. $34 \mathrm{G}>\mathrm{T}$ & + & no & yes & 0 & no & $S$ & + \\
\hline 44 & no & c.34G $>T$ & ++ & & & $0 /+$ & & $S$ & + \\
\hline
\end{tabular}

Blank cells: not done/not ascertainable, $\dagger 0=$ none, $+=>0<25 \%,++=25-75 \%,+++>75 \%$, *previously reported mutations, see http:// www.sanger.ac.uk/genetics/CGP/cosmicl (SMAD4) and http://p53.free.fr/index.html (P53), @LOH, as reported by Middeldorp et al (mainly copy neutral LOH and not physical loss), ${ }^{8}+\dagger \mathrm{O}=$ category I (membranous staining), $0 /+=2 \mathrm{~A}$ (membranous and some nuclear staining), $+=2 \mathrm{~B}$ (membranous \& increased nuclear staining), $++=3$ (strong nuclear \& less or no membranous staining), $\sim 2 / 9$ markers unstable.

and in these carcinomas other hotspot mutations are found, namely the c.35G $>\mathrm{A}$ and c.38G $>\mathrm{A}$, compromising $81 \%$ of detected KRA2S mutations in these tumours. [41] Previously we have shown that KRAS2 hotspot analysis can be used to detect MAP tumours.[5] Since KRAS2 mutations have been found previously in aberrant crypt foci (ACF) as well,[42] the high prevalence of KRAS2 mutations might influence tumourigenesis in MAP.

Nuclear staining indicative of p53 dysfunction was found in 34\% in this study, which is less than found in sporadic carcinomas (57\%, Table 2A). We found $p 53$ mutations in $60 \%$ of carcinomas analyzed; this finding, along with the presence of $\mathrm{LOH}$, correlated with the IHC staining results (Table 4). Three mutations were typical MUTYH G>T transversions. Lipton et al. found nuclear staining in 53\% of MAP carcinomas, but $p 53$ mutations in only $21 \%$ (of which a minority were $G>T$ transversions), suggesting an alternative mechanism of over-expression.[11] The employment of tissue arrays for the current study could imply an underestimation of cases with both p53 and beta-catenin accumulation in the nucleus. However, we reported that 3 punches representing one tumour in a TMA correctly recapitulated the observations made on analysis of the whole slides.[27].

SMAD4 somatic mutations in this series were present in $26 \%(5 / 19$, Table 4$)$. Lipton et al. did not find any SMAD4 mutations in MAP CRCs, but did find $18 \mathrm{q} \mathrm{LOH}$ at the same frequency as in sporadic CRCs.[11] Recently we reported that the chromosome $18 \mathrm{q} \mathrm{LOH}$ in MAP carcinomas mainly comprises copy neutral LOH and not physical loss, as observed in sporadic CRC.[13]

In the early stages of MAP tumourigenesis, a dominance of the BER defect can be concluded from the high frequency 

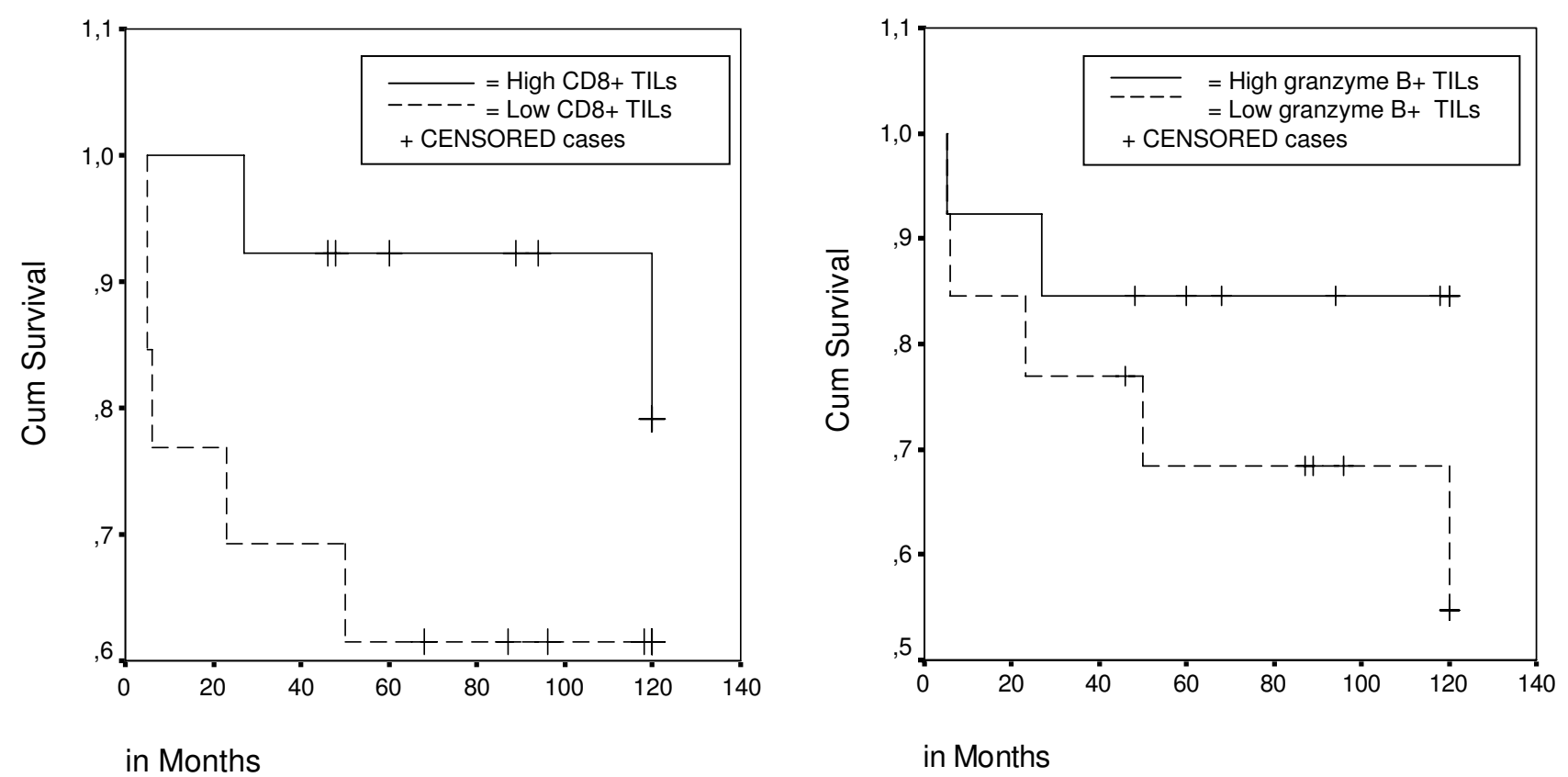

Figure 2

Survival in 26 MAP patients, according to $\mathrm{CD}^{+}$status and granzyme $\mathrm{B}^{+}$status. high versus low, median, number of TILs as cut off point. Log rank; $P=0.15\left(\mathrm{CD}^{+}\right)$and Log rank; $P=0.2$ (granzyme $\left.\mathrm{B}^{+}\right)$.

of $\mathrm{G}>\mathrm{T}$ tranversions in KRAS2 and APC. In the later stages such $\mathrm{G}>\mathrm{T}$ transversions seem less prominent, as seen in $S M A D 4$ and $p 53$. Mitotic recombination might be a driving force in MAP carcinogenesis, based on our conclusion that the LOH in MAP carcinomas mainly comprise copy neutral LOH. Two previous studies by Colebatch and Lefevre et al.[43,44] have suggested that MAP CRCs can also develop through a MSI pathway (by inactivation of $M L H 1$ ) because of the finding of MSI-high phenotype in one out of three and one out of six MAP CRCs, respectively. O'Shea et al. found MMR deficiency in 2 out of 11 tumours (18\%). However, on the basis of the results of this study (an absence of MSI-high in 35 analyzed carcinomas), we conclude that the MSI pathway is not an important pathway in the development of MUTYH associated tumours.

\section{Conclusion}

MAP CRCs as a group show specific histological features that differentiate them from sporadic CRCs, and have similarities with sporadic MSI-high and Lynch syndrome colon cancers, such as a preferential proximal location, mucinous histotype, and increased presence of TILs. These TILs might suggest that defects in base excision repair, similar to mismatch repair deficiency, produce secondary aberrant proteins functioning as tumour-specific neoantigens that, in turn, induce anti-tumour immune responses. Further evidence for MAP can be assembled by the detec- tion of c.34G>T transversion in KRAS2 that takes place in early tumour development. KRAS2 analysis can be implemented as a pre-screening test that helps selecting CRC patients eligibly for germline MUTYH mutation testing. In practice, above features should direct the pathologist towards a MAP aetiology of CRC as an alternative for a mismatch repair deficient cause, especially when diagnosed at a young age and in combination with polyps and/or a recessive inheritance pattern.

\section{Competing interests}

The authors declare that they have no competing interests.

\section{Authors' contributions}

$\mathrm{MN}, \mathrm{NFCCM}, \mathrm{MvP}, \mathrm{AM}, \mathrm{RvE}$ and CMJT carried out the molecular genetic studies. MN, NFCCM, MvP, AM and RvE carried out the sequence analyses. MN, MvP, RvE, CMJT, AM, HFAV, FJH and HM carried out the acquisition, analysis and interpretation of data. MN and NFCCM performed the statistical analysis. MN, NFCCM, HFAV, FJH and HM drafted the manuscript. ESJ carried out the immunoassays. MN, NFCCM, ESJ, TvW, FJH and HM participated in the design of the study. NFCCM, ESJ, TvW, HFAV, FJH and HM revised the manuscript critically for important intellectual content. HM participated in its design and coordination. All authors read and approved the final manuscript. 


\section{Additional material}

\section{Additional file 1}

Histological and molecular features in carcinomas, extended version of table 2. Blank cells: not done/not ascertainable, $+0=$ none,$+=$ $>0<25 \%,++=25-75 \%,+++>75 \%$, * previously reported mutations, see http://www.sanger.ac.uk/genetics/CGP/cosmic/ (SAMD4) and http:// p53.free.fr/index.html (P53), @LOH, as reported by Middeldorp et al (mainly copy neutral LOH and not physical loss), $8++0=$ category 1 (membranous staining), $0 /+=2 \mathrm{~A}$ (membranous and some nuclear staining), $+=2 B$ (membranous \& increased nuclear staining), $++=3$ (strong nuclear \& less or no membranous staining), ${ }^{* *}+=$ nuclear staining, heterogenous = absent nuclear staining in part of tumour tissue, $0=$ no nuclear staining $\pm / \pm=$ weak nuclear staining, $\sim 2 / 9$ markers unstable. Click here for file

[http://www.biomedcentral.com/content/supplementary/14712407-9-184-S1.doc]

\section{Acknowledgements}

We would like to thank the following hospitals (pathology departments) for providing tissue blocks: Academical Medical Center (Amsterdam), Amphia hospital (Breda), Atrium Medical Center (Heerlen), Bethesda hospital (Hoogeveen), Bronovo hospital (Den Haag), Isala hospital (Zwolle), Jeroen Bosch hospital (Den Bosch), Erasmus Medical Center (Rotterdam), Laboratorium Pathologie Oost Nederland (LabPON, Enschede), Laboratoria voor Pathologie en Medische Microbiologie (PAMM, Eindhoven/Veldhoven), Meander hospital (Amersfoort), Medisch Centrum Haaglanden (Den Haag), the Netherlands Cancer Insitute (Amsterdam), Onze Lieve Vrouwe Gasthuis (Amsterdam), Radboud University Nijmegen Medical Center (Nijmegen), Reinier de Graaf Groep (SSDZ, Delft), Rijnland Hospital (Leiderdorp), University Medical Center Utrecht (Utrecht), University Medical Center Groningen (Groningen), VieCuri, Medical Centre (Venlo and Venray), VU University Medical Center (Amsterdam), Zaans Medisch Centrum (Zaanstad).

\section{References}

I. Croitoru ME, Cleary SP, Di Nicola N, Manno M, Selander T, Aronson $M$, et al.: Association between biallelic and monoallelic germline MYH gene mutations and colorectal cancer risk. J Natl Cancer Inst 2004, 96:163I-1634.

2. Wang L, Baudhuin LM, Boardman LA, Steenblock KJ, Petersen GM, Halling KC, et al: MYH mutations in patients with attenuated and classic polyposis and with young-onset colorectal cancer without polyps. Gastroenterology 2004, 1 27:9-16.

3. Nielsen M, Franken PF, Reinards TH, Weiss MM, Wagner A, van der $\mathrm{KH}$, et al:: Multiplicity in polyp count and extracolonic manifestations in 40 Dutch patients with MYH associated polyposis coli (MAP). J Med Genet 2005, 42:e54.

4. Aretz S, Uhlhaas S, Goergens H, Siberg K, Vogel M, Pagenstecher C, et al: MUTYH-associated polyposis: 70 of 71 patients with biallelic mutations present with an attenuated or atypical phenotype. Int / Cancer 2006, I | 9:807-8|4.

5. Van Puijenbroek M, Nielsen M, Tops CM, Halfwerk H, Vasen HF, Weiss MM, et al.: Identification of Patients with (Atypical) MUTYH-Associated Polyposis by KRAS2 c.34G > T Prescreening Followed by MUTYH Hotspot Analysis in Formalin-Fixed Paraffin-Embedded Tissue. Clin Cancer Res 2008, 14:139-142.

6. Balaguer F, Castellvi-Bel S, Castells A, Andreu M, Munoz J, Gisbert JP, et al.: Identification of MYH mutation carriers in colorectal cancer: a multicenter, case-control, population-based study. Clin Gastroenterol Hepatol 2007, 5:379-387.

7. Farrington SM, Tenesa A, Barnetson R, Wiltshire A, Prendergast J, Porteous M, et al.: Germline susceptibility to colorectal cancer due to base-excision repair gene defects. Am J Hum Genet 2005, 77: I12-119.

8. Grunhage F, Jungck M, Lamberti $C$, Schulte-Witte $H$, Plassmann D, Becker U, et al:: Contribution of common monoallelic MUTYH gene variants in German patients with familial colorectal cancer. Cancer Biomark 2008, 4:55-6I.

9. Avezzu A, Agostini M, Pucciarelli S, Lise M, Urso ED, Mammi I, et al:: The role of MYH gene in genetic predisposition to colorectal cancer: another piece of the puzzle. Cancer Lett 2008, 268:308-3।3.

10. Al Tassan N, Chmiel NH, Maynard J, Fleming N, Livingston AL, Williams GT, et al:: Inherited variants of MYH associated with somatic G:C-->T:A mutations in colorectal tumours. Nat Genet 2002, 30:227-232.

II. Lipton L, Halford SE, Johnson V, Novelli MR, Jones A, Cummings C, et al:: Carcinogenesis in MYH-associated polyposis follows a distinct genetic pathway. Cancer Res 2003, 63:7595-7599.

12. Andreyev HJ, Norman AR, Cunningham D, Oates J, Dix BR, lacopetta $\mathrm{BJ}$, et al: Kirsten ras mutations in patients with colorectal cancer: the 'RASCAL II' study. Br J Cancer 200I, 85:692-696.

13. Middeldorp A, Van Puijenbroek M, Nielsen M, Corver W, Jordanova E, Ter Haar N, et al:: High frequency of copy-neutral LOH in MUTYH-associated polyposis carcinomas. J Pathol 2008, 216:25-31.

14. Dolcetti R, Viel A, Doglioni C, Russo A, Guidoboni M, Capozzi E, et al.: High prevalence of activated intraepithelial cytotoxic $T$ lymphocytes and increased neoplastic cell apoptosis in colorectal carcinomas with microsatellite instability. Am J Pathol 1999, 154:1805-1813.

15. Alexander J, Watanabe T, Wu TT, Rashid A, Li S, Hamilton SR: Histopathological identification of colon cancer with microsatellite instability. Am J Pathol 200 I, I 58:527-535.

16. Ribic CM, Sargent DJ, Moore MJ, Thibodeau SN, French AJ, Goldberg $\mathrm{RM}$, et al.: Tumor microsatellite-instability status as a predictor of benefit from fluorouracil-based adjuvant chemotherapy for colon cancer. N Engl J Med 2003, 349:247-257.

17. Galon J, Costes A, Sanchez-Cabo F, Kirilovsky A, Mlecnik B, LagorcePages $C$, et al:: Type, density, and location of immune cells within human colorectal tumours predict clinical outcome. Science 2006, 313:1960-1964.

18. Hamilton SR, Aaltonen LA, Eds: World Health Organization Classification of Tumours. Pathology and Genetics of Tumours of the Digestive System. Lyon, IARC Press; 2000.

19. Moertel CG, Bargen JA, Dockerty MB: Multiple carcinomas of the large intestine: a review of the literature and a study of 261 cases. Gastroenterology 1958, 34:85-98.

20. Graham DM, Appelman HD: Crohn's-like lymphoid reaction and colorectal carcinoma: a potential histologic prognosticator. Mod Pathol 1990, 3:332-335.

21. de Jong $A E$, Van Puijenbroek M, Hendriks $Y$, Tops $C$, Wijnen J, Ausems MG, et al: Microsatellite instability, immunohistochemistry, and additional PMS2 staining in suspected hereditary nonpolyposis colorectal cancer. Clin Cancer Res 2004, 10:972-980.

22. Boland CR, Thibodeau SN, Hamilton SR, Sidransky D, Eshleman JR, Burt RW, et al.: A National Cancer Institute Workshop on Microsatellite Instability for cancer detection and familial predisposition: development of international criteria for the determination of microsatellite instability in colorectal cancer. Cancer Res 1998, 58:5248-5257.

23. Nielsen M, Poley JW, Verhoef S, Van Puijenbroek M, Weiss JM, Burger GT, et al.: Duodenal carcinoma in MUTYH-associated polyposis coli. J Clin Pathol 2006, 59:12 I2-1215.

24. LUMC, DNA-diagnostics 2009 [http://www.lumc.nl/4080/DNA/ MUTYH.html]. Ref Type: Internet Communication

25. Leiden Open Variation Database 2009 [http://chromium.liacs.nl/ LOVD2/home.php?select db=MUTYH]. Ref Type: Internet Communication

26. Fokkema IF, den Dunnen JT, Taschner PE: LOVD: easy creation of a locus-specific sequence variation database using an "LSDBin-a-box" approach. Hum Mutat 2005, 26:63-68.

27. Hendriks Y, Franken P, Dierssen JW, De Leeuw W, Wijnen J, Dreef $\mathrm{E}$, et al: Conventional and tissue microarray immunohistochemical expression analysis of mismatch repair in hereditary colorectal tumours. Am J Pathol 2003, 162:469-477. 
28. van Vlierberghe RL, Sandel MH, Prins FA, van lersel LB, Velde CJ Van De, Tollenaar RA, et al.: Four-color staining combining fluorescence and brightfield microscopy for simultaneous immune cell phenotyping and localization in tumor tissue sections. Microsc Res Tech 2005, 67:15-21.

29. The p53 WebB Site 2009 [http://p53.free.fr/index.html]. Ref Type: Internet Communication

30. Sankila R, Aaltonen LA, Jarvinen HJ, Mecklin JP: Better survival rates in patients with MLH I-associated hereditary colorectal cancer. Gastroenterology 1996, I l 0:682-687.

31. O'Shea AM, Cleary SP, Croitoru MA, Kim H, Berk T, Monga N, et al.: Pathological features of colorectal carcinomas in MYH-associated polyposis. Histopathology 2008, 53:184-194.

32. Viel A, Genuardi M, Lucci-Cordisco E, Capozzi E, Rovella V, Fornasarig $M$, et al.: Hereditary nonpolyposis colorectal cancer: an approach to the selection of candidates to genetic testing based on clinical and molecular characteristics. Community Genet 1998, I:229-236.

33. Guidoboni M, Gafa R, Viel A, Doglioni C, Russo A, Santini A, et al.: Microsatellite instability and high content of activated cytotoxic lymphocytes identify colon cancer patients with a favorable prognosis. Am J Pathol 200I, I 59:297-304.

34. Menon AG, Janssen-van Rhijn CM, Morreau $\mathrm{H}$, Putter $\mathrm{H}$, Tollenaar RA, Velde CJ Van De, et al.: Immune system and prognosis in colorectal cancer: a detailed immunohistochemical analysis. Lab Invest 2004, 84:493-50I.

35. Samowitz WS, Slattery ML, Sweeney C, Herrick J, Wolff RK, Albertsen $\mathrm{H}$ : APC mutations and other genetic and epigenetic changes in colon cancer. Mol Cancer Res 2007, 5:165-170.

36. Miyaki M, Konishi M, Kikuchi-Yanoshita R, Enomoto M, Igari T, Tanaka $\mathrm{K}$, et al.: Characteristics of somatic mutation of the adenomatous polyposis coli gene in colorectal tumours. Cancer Res 1994, 54:30I I-3020.

37. Miyoshi $Y$, Nagase $H$, Ando $H$, Horii A, Ichii $S$, Nakatsuru $S$, et al.: Somatic mutations of the APC gene in colorectal tumours: mutation cluster region in the APC gene. Hum Mol Genet I992, I:229-233.

38. Luchtenborg M, Weijenberg MP, Roemen GM, de Bruine AP, Brandt PA van den, Lentjes $M H$, et al: APC mutations in sporadic colorectal carcinomas from The Netherlands Cohort Study. Carcinogenesis 2004, 25:1219-1226.

39. Lips EH, van ER, de Graaf EJ, Doornebosch PG, de Miranda NF, Oosting J, et al:: Progression and tumor heterogeneity analysis in early rectal cancer. Clin Cancer Res 2008, I 4:772-78I.

40. Jones S, Lambert S, Williams GT, Best JM, Sampson JR, Cheadle JP. Increased frequency of the k-ras GI2C mutation in MYH polyposis colorectal adenomas. Br J Cancer 2004, 90: | 59|-I593.

4I. Oliveira C, Westra JL, Arango D, Ollikainen M, Domingo E, Ferreira $A$, et al:: Distinct patterns of KRAS mutations in colorectal carcinomas according to germline mismatch repair defects and hMLHI methylation status. Hum Mol Genet 2004, I 3:2303-23 I I.

42. Pretlow TP, Pretlow TG: Mutant KRAS in aberrant crypt foci (ACF): initiation of colorectal cancer? Biochim Biophys Acta 2005, I 756:83-96.

43. Colebatch A, Hitchins M, Williams R, Meagher A, Hawkins NJ, Ward RL: The role of $M Y H$ and microsatellite instability in the development of sporadic colorectal cancer. Br J Cancer 2006, 95: $1239-1243$

44. Lefevre JH, Rodrigue CM, Mourra N, Bennis M, Flejou JF, Parc R, et al.: Implication of MYH in colorectal polyposis. Ann Surg 2006, 244:874-879.

\section{Pre-publication history}

The pre-publication history for this paper can be accessed here:

http://www.biomedcentral.com/1471-2407/9/184/pre pub
Publish with Biomed Central and every scientist can read your work free of charge

"BioMed Central will be the most significant development for disseminating the results of biomedical research in our lifetime. "

Sir Paul Nurse, Cancer Research UK

Your research papers will be:

- available free of charge to the entire biomedical community

- peer reviewed and published immediately upon acceptance

- cited in PubMed and archived on PubMed Central

- yours - you keep the copyright

Submit your manuscript here:

http://www.biomedcentral.com/info/publishing_adv.asp
BioMedcentral 